two pages of text. Mr. Hawken and the LTP have followed their Photocopying From Bound Volumes with a worthy successor.Hubbard W. Ballou, Columbia University Libraries.

Engineering Data Microreproduction Standards and Specifications. By the United States Department of Defense. (Informational Monograph No. 1) Annapolis, Md.: National Microfilm Association, 1963. 15lp. \$3.

A phrase that occurs many times in variant forms in William Hawken's recent book on enlarged prints from microforms is: "This machine was never designed to reproduce the diverse sizes and types of documents which make up library collections of microforms." In his summary chapter he throws down his gage before the equipment manufacturers challenging them to: “. . . take another look at the library world, its vast holdings of microforms, and its needs." We can say "Hear, hear!" to this, but in all honesty can we not grant the manufacturers a valid counter-challenge to us to do something about standardizing the production of our library microforms, so that they may design us simplified and inexpensive models?

A field which was faced with a similar problem was that of engineering drawing files. The Department of Defense wanted to simplify the storage, dissemination, and reproduction of these bulky items through use of microfilm. These drawings occur in multifarious sizes and of indescribably varying qualities of legibility. The only way to make the system work was by standardization all along the line: production of the original drawing, filming, processing, mounting the film in tab cards, and reproduction through numerous generations to the final paper print output.

The National Microfilm Association has been active in the progress of the Engineering Data Microreproduction System since serious work began on it about 1956. The association, at its San Francisco convention in April 1963, reprinted the many scattered specifications that were the outgrowth of this program. Though available as twelve separate specifications from the various agencies involved, this package publication is the easiest and cheapest way to acquire the series. Written as federal specifications are, they are not designed as light reading matter; but there is much food for thought buried beneath the official jargon. Libraries can learn by analogy from problems faced by the DOD EDMS program, and get what cheer they can from knowing that other users of microreproductions have met the same problems. One warning is necessary, however, and that is that the two problems are similar but not replicas of each other. We must pick and choose those points of similarity with care, and not try to specify all items from the DOD specs every time we place an order for microfilming.-Hubbard W. Ballou, Columbia University Libraries.

\section{Latin American Directory}

Guia de Bibliotecas de la América Latina. Edición provisional. (Pan American Unión, Columbus Memorial Library. Bibliographic Series, no. 51) Washington: Union Panamericana, 1963. viii 165 p. $\$ 5$.

For some time the lack of a guide to Latin American libraries-similar to the American Library Directory-has hampered persons needing information about such institutions. The many changes in the library picture there since 1942 have, of course, rendered Rodolfo O. Rivera's Preliminary List of Libraries in the Other American Republics inadequate for most purposes. The present compilation, prepared by the Pan-American Union's Library Development Program, while not fully comparable to the Bowker list, represents a step in the right direction.

Although the compilers have not attempted to include all Latin American libraries, their aim was to present all university and special libraries, public libraries of more than two thousand volumes, and school libraries of more than one thousand volumes; they recognize that, even with these limits, they have probably missed some institutions. Nevertheless, the user finds approximately twenty-two hundred libraries (vs. five thousand in the less selective $\mathrm{Ri}$ vera list); there is a section for each of the twenty Latin American republics and Puer- 